\title{
Introductory Remarks on Ideology and Sociology
}

Franco Ferrarotti

Prof. Emeritus of La Sapienza University, Italy

Founder of La Critica Sociologica

\section{Abstract}

The main contention of this paper is that the eventual decline of ideology would pave the way to personalism and piece-meal policy-making. In this respect, sociology should analyze the process of social evolution while the ideological goals tend to concentrate on the middle-range and distant future.

Keywords: ideological utopianism; personalistic leadership; social process; rational analysis.

\section{Introduction}

The relationship between ideology and sociology constitutes a complicated, interesting and, at times, disturbing picture ${ }^{1}$.

Interwoven as they are, they seem to have been fighting each other continuously since the very beginning (in Comte even before Marx): ideology as an act of impatience, the desire to have certainty beyond evidence, and sociology as a careful retrieving of motives and actualities. And yet, they emerge as necessary to each other as the over-all meaningful reaching towards a set of goals and the analysis of how to get there and whether the effort is worth while, as total assertion of values and the permanent casting of a doubt.

\section{Three traditional sociological ways of looking at ideology}

A first, cursory examination can probably detect three traditional sociological ways of looking at ideology:

(a) as a cultural system, or system of notions concerning various aspects of social life, whose main function appears to be twofold - of building and perpetuating internal group-cohesion as regards its members, and of insuring a sufficient degree of group-integration with respect to the global structure of society. These notions do not necessarily have to be lies or distorted views, but usually they do not resist scientific analysis; their value as social tools, that is in terms of their effectiveness in orienting the group, does not, however, depend on their empirical verification;

\footnotetext{
${ }^{1}$ For a panoramic view, see Kurt Lenk, editor, Ideologie, Neuwied, 1961.
} 
(b) as a pure and simple conjecture which is difficult to refute because of its intrinsic vagueness or complexity and which usually expresses an individual or group preference which would not normally be shaken by the demonstration that it is empirically groundless or logically untenable; and

(c) finally, as the expression in general universal terms of standpoints which are historically determined in such a way as to regard as "eternal values» and invariable principles historical specific traits and intellectual positions which are in fact quite variable, at least in the sense that they are relative to a given historical period and society ${ }^{2}$.

Closer scrutiny of the notion of ideology is likely to show that in the social science literature there are many contrasting and overlapping definitions of it, ranging from the concept of ideology as the "original vision" and pre-scientific insight ${ }^{3}$ to the concept of ideology as a "pure error» and "psychological deformation ${ }^{4}$. In between these two polar concepts there is a variety of more or less elaborate conceptions and opinions which could perhaps be summarized as follows:

(a) ideology as a relatively coherent body of beliefs about the various aspects of society, that is, as a cultural system and a guide for policy;

(b) as lore, or pre-scientific knowledge, imbued with ethical common sense implications for behaviour;

(c) as an activistic aspiration offering a sense of direction for group-behaviour;

(d) as a «false» or «mystified» consciousness related to practical economic interests;

(e) as a non-scientific theory;

(f) as a rationalization of the status quo;

(g) as a doctrinaire dogmatic design to change the existing social and political situation.

\footnotetext{
${ }^{2}$ For an excellent account, see G. Lichtheim, «The Concept of Ideology», History and Theory, IV, 2, 1965, pp. 164-195.

${ }^{3}$ Cfr. Joseph A. Schumpeter, "Science and Ideology», The American Economic Review, XXXIX, 2 March 1949, pp. 345-359. Schumpeter applies his notion of ideology to the explanation of the economic thought of Adam Smith, Marx and Keynes. But the relation between their thinking and their personal and ancestral class affiliation is emphasized by him rather mechanically.

${ }^{4}$ Werner Stark, The Sociology of Knowledge, London, 1958, esp. Part One, Ch. II. Stark excludes the study of ideology from the sociology of knowledge because, according to him, whereas socially determined knowledge shares in the truth, ideologies are pure and simple lies.
} 


\section{The sociological study of ideology and social research}

Disregarding for the time being these conflicting and overlapping definitions, there can be little doubt that the sociological study of ideology indicates an important and baffling area of social research ${ }^{5}$.

The relationship between ideology and sociology is not an easy one. The fact that ideology is in itself an allusive term which has become thoroughly ideologized, as Clifford Geertz has pointed out ${ }^{6}$, is not the only reason. The matter seems to go somewhat deeper and it involves sociology as a specific discipline and its orientation. While, on the one hand, ideology has been seen by some sociologists as exhausted, or "come to an end ${ }^{\prime}{ }^{7}$, sociology on the other hand is being regarded in some quarters as, first, an essentially manipulative device, whereby the ideological tension towards changing the existing social and economic conditions is wisely diluted and finally eliminated, and, secondly, as nothing more than the substitute, at best the compensation, for the unfilled ideological promise. In other words, the sociologist would only be a disappointed ideologist, and social science itself, that is the quest for reliable information about and understanding of social structures (institutions) and behaviour, nothing but a carefully planned flight from personal anxiety or commitment. This kind of criticism was quite familiar, in a strongly polemical vein, with $\mathrm{G}$. Lukács with respect to Max Weber and other bourgeois sociologists. The attempt by Weber to go beyond the typical one-sidedness of Marxian and Engelsian analysis was here presented as a revealing example of division of labour as reflected in the specialistic separation of the social sciences, in particular in the separation of sociology from economics. It is true however, that Lukács saw Marxism itself as historically conditioned and implied the necessity of transforming it in concomitance with the evolution of capitalist society. From this point of view, the relevance of Weber's work becomes apparent. As has been aptly remarked by G. Lichtheim, "Weber did not really 'turn Marx upside down' [...] but rather developed a bourgeois counterpart to the Marxian theory of history». But Lichtheim recognizes that, in one important respect, Weber went beyond Marx, namely "... in that his sociology concerned 'industrial society' as such; it thus became relevant, for capitalism and socialism alike $»^{8}$. We shall see later that things are in this connection not as obvious as they appear to be and that further research is needed.

\footnotetext{
${ }^{5}$ For a comprehensive critical survey, see N. Birnbaum, "The Sociological Study of Ideology (1940-1960)», Current Sociology, 1960, n. 2.

${ }^{6}$ C. Geertz, «Ideology as a Cultural System», in David E. Apter, ed., Ideology and Discontent, London, 1964, p. 47.

${ }^{7}$ For the most elaborate and articulate treatment of this point of view, see Daniel Bell, The End of Ideology, Glencoe, 1960; among the first writers to deal with this subject, see L. S. Feuer, "Beyond Ideology», in Psychoanalysis and Ethics, Springfield, 1955, pp. 126-130. For a stress on the intrinsic limitations of individuals to act rationally, see George H. Sabine, "Beyond Ideology», The Philosophical Review, LVII, 1948, pp. 1-25; Max Horckheimer, Eclipse of Reason, New York, 1947.
}

${ }^{8}$ Cfr. G. Lichtheim, op. cit., p. 186; see also my Max Weber e il destino della ragione, Bari, 1965, esp. pp. 34-35. 


\section{Evaluative commitments as statements of fact}

It seems that a curious fact must be taken into consideration: we live in an age of personal, evaluative commitments and judgments, which, by every count, appear to be ashamed of themselves and would rather be regarded as statements of fact, if not scientific propositions altogether.

The fear of ideological contamination is widespread. Recent writings concerning democracy and its problems, for example, to go great pains to avoid any ideological overtones and to establish a claim to scientific status although their ideological nature becomes apparent when they finally hold up the Western democratic form of government as an historical nec plus ultra ${ }^{9}$. There is a good reason for all this. Gustav Bergmann has observed that "as we survey man's history, we cannot, I believe, escape the following conclusion: the motive power of a value judgment is often greatly increased when it appears within the rationale of those who held it not under its proper logical flag as a value judgment but in the disguise of a statement of fact $\aleph^{10}$. The instrumental nature of ideologies seems to be out of the question. A characteristic distortion is also present in them. In the history of Western culture, the idea that certain ways of thinking are capable of falsifying whatever they come into contact with is undoubtedly of a religious nature; it evokes the idea of the "false prophet». But what is most important to note is that the thesis of the end of ideology can easily be presented as a new ideology, that is as another ideological "trick» pretending to smuggle a personal or group-belief as «a factual version of the world» $»^{11}$.

Together with other catch phrases such as the "affluent society", and "neo-capitalism», the end of ideology has been subjected to a lengthy and, at times, ungenerous examination ${ }^{12}$. According to Meynaud, the phenomenon, which has been brilliantly and profusely described especially by Raymond Aron and Daniel Bell, is probably a real one, at least for the technically advanced and economically mature societies, but its significance and implications have been grossly exaggerated. With a kind of vitriolic light touch he reviews most of the points made in this connection by Raymond Aron, Maurice Duverger, John K. Galbraith, Daniel Bell,

\footnotetext{
${ }^{9}$ Cfr. especially, among others, Gabriel A. Almond and Sidney Verba, The Civic Culture, Princetown, 1963; Bertrand de Jouvenel, The Pure Theory of Politics, Cambridge, 1963; William Kornhauser, The Politics of Mass Society, Glencoe, 1959; Seymour M. Lipset, Political Man, New York, 1960. According to William G. Runciman, «the point is not that such propositions about political behaviour cannot be made, but that no properly explanatory or interpretative propositions about it can be 'scientific' in the naturwissenschaftlich sense distinction. Explanations, or interpretations, of political behaviour must be unscientific not because they are prescriptive statements in disguise (although this is sometimes so) but because they are in some other sense evaluative statements, as all historical explanations and interpretations must be»; Archives Européens de Sociologie, VI, 1, 1965, p. 175.

${ }^{10}$ Cfr. G. Bergmann, «Ideology», Ethics, LXI, April 1951, 3, p. 210.

${ }^{11}$ Cfr. G. Bergmann, op. cit., p. 92.

12 Jean Meynaud, Destin des idéologies, Lausanne, 1961; cfr. Also, Stephen W. Rousseau and James Farganis, «American Politics and the End of Ideology», The British Journal of Sociology, XIV, 4, December 1963, pp. 347-362; James Petras, "Ideology and United States Political Scientists», Science and Society, XXIX, 2, Spring 1965, pp. 192-216.
} 
Seymour M. Lipset, not to mention Arthur Koestler ${ }^{13}$, and sums up his thinking by saying that the phenomenon, if real, seems also typical of a stage of transition. The interpretation of it should be cautious, especially when it comes to prediction for future developments. As a basis for generalizations what we know about it is too little and ambiguous. For instance, lack of citizens' participation in political affairs, far from indicating a decline in ideological passion, could simply mean a passionate, total, «ideological» refusal of the institutional instruments and of the prevailing conditions under which political life develops itself. Moreover, it is undoubtedly true that both right and left nowadays accept (but only in Western democratic societies, and this should not be forgotten, lest the charge of «provincialism» made by $\mathrm{C}$. Wright Mills should appear correct) a certain measure of public intervention in economic affairs and, in general, what could be regarded as a «mixed» economic system, but it is equally true that the right wing keeps thundering against "dirigisme» and that the left wing advocates «socialism» without adjectives, here and now, in the best maximalistic tradition.

To talk and to write about a post-ideological society in which social conflicts appear to be "aseptic» as it were, and only factually or technically motivated, is at least premature. There is no doubt that in the long run important qualitative changes and transformations take place, but this is a matter of research, not of speculation. At any rate, it does not necessarily imply the pure and simple liquidation of ideologies conceived as ideal projections in universal terms of interests and standpoints, which are of a sectional character. It might simply mean the emergence of new ideologies.

\section{The end of ideological enthusiasms and the sociological analysis as an attempt of persuasion}

In fact, even the writers mentioned above, in their effective treatment of the decline and of the end of «ideological enthusiasms», as Shils put it, seem to slide at times and sensim sine sensu back from the standpoint of sociological analysis into an attempt of persuasion.

This becomes disturbingly apparent in the selective underlining of the positive aspects of specific economic, political and social situations and the relative neglect of other aspects, which are equally real, in the nearly obsessive denunciation of dogmatism and lack of moderation, and in offering a compromise solution for any kind of problem. These compromise solutions, however, are not offered as such, but rather as if they were the only rational answer, something quite objectively imposed, as it were, by

\footnotetext{
${ }^{13}$ See R. Aron, L'opium des intellectuels, Paris, 1955 ; John K. Galbraith, The Affluent Society, New York, 1958; Maurice Duverger, De la dictature, Paris, 1961; A. Koestler, L'ombre du dinosaure, Paris, 1956, see also in S. M. Lipset, Political Man, cit., Ch. XIII, «The End of Ideology?», pp. 403-417; E. A. Shils, "The End of Ideology», Encounter, Nov. 1955, pp. 52-58, and The Torment of Secrecy, Glencoe, 1956, Ch. XII, «Ideological Politics», pp. 231-238.
} 
a substantial rationality, which would have nothing to do with personal (ideological) principles of preference.

Meynaud takes as an outstanding example of this selective technique The Affluent Society by John K. Galbraith to show how only the rosy passages and the felicitous descriptions of American opulence are recalled and commented upon, while the bitter pages in which, in a somewhat Veblenian mood, Galbraith writes about the conspicuous waste vis-à-vis the chronic deficiencies of elementary community services (housing, schools, hospitals) are usually subjected to a Freudian evasion and neglected, if not altogether forgotten. According to its main contention - that the concentration on production will finally result in the pre-dominance of the productive sphere over and against capacity to consume to such an extent that the "affluent society" would have to invent imaginary needs to survive - the book is clearly mistitled unless it is meant to convey an idea of sinister irony. On the other hand, Galbraith is himself quite optimistic about the future and seems to enjoy his extraordinary gift for phrase-making, already apparent in his early work on American Capitalism and his quasi-proudhonian concept of "countervailing power», without feeling any urgency to go much beyond the paradox to find the possible structural causes of work behind the disconcerting and even amusing contradictions of an industrially advanced society. Simple, factual questions are left open: is it true that economic inequality is no longer a problem in an industrially advanced society and that, as a consequence, ideological passions have lost one of their important motives? Is it true that economic insecurity is no longer there, not even when a society is faced by rapid technological change making for radical and at times psychologically unacceptable retraining of vast sectors of the labour force? A broad and many-sided field for social research is here open to sociologists. The study of the specifically ideological components of the process of social and cultural change would certainly help in the elaboration of an integrated theory of culture and its development ${ }^{14}$.

It could be, Meynaud goes on to suggest, that the thesis of the end of ideology is merely a tactical (ideological) move to discourage, as no longer necessary or practical, any attempt towards a structural change in society. It is only natural to expect that a suspicion of this kind would arouse the biblical anger of a social critic such as C. Wright Mills, who not only denies scientific dignity to the end-of-ideology point of view but sees it quite conspiratorially as a «weary know-it-all justification - by tone of voice rather than by explicit argument - of the cultural and political default of the

\footnotetext{
${ }^{14}$ There is a growing body of literature on change, social and cultural. Economists have in general recognized the impossibility of an exhaustive explanation of economic development in purely economic terms, but Everett E. Hagen is right when he laments that these are purely verbal admissions with no detectable consequences on research; cfr. E. E. Hagen, On the Theory of Social Change, Homewood, 1962, p. 37. The fact is that, once the inadequacy of the economic explanation is recognized, the very autonomy of economics as a specific, self-sufficient discipline is a danger.
} 
NATO intellectuals $»^{15}$. Yet, what has happened to ideology in industrially developed societies should not be impossible to identify on a factual basis, both with regard to the ruling group or "catégories dirigeantes» and to the employees or working classes. But the difficulty here begins with the very concept, and term, of industrial society. Can one speak of industrial society per se without making explicit reference of its "capitalistic» or "socialistic» or «mixed» nature? Is the term industrial by itself sufficient to differentiate it qualitatively from other historical types of society? ${ }^{16}$

\section{Industrial society instead of Capitalist society}

Some sociologists, in Europe, in the United States, and in the Soviet Union, ask themselves somewhat melodramatically whether one can speak of «industrial society» or whether one should, more appropriately, speak of a «capitalist» society.

In their opinion, the adjective «industrial» is not revealing, or sanguine enough. It necessarily implies a dilution of the ideological tension, making for a situation socially neutral, and ideologically indifferent. It is an escape. According to this view, the term "industrial society» is adopted more willingly by social scientists than such terms as "capitalist society" or "socialist society" simply to avoid the embarrassment of a clear-cut position and commitment ${ }^{17}$. The generic connotation of «industrial» would in particular blur the principal characteristics of a technically advanced society while neglecting is structural economic features in favour of the supposedly secondary, or purely concomitant aspects of its evolutionary process. Undoubtedly, the term "capitalist society» indicates more directly a social and economic situation in which private property is accepted and formally codified and power relationships among social groups and classes currently develop and are recognized and eventually disciplined as such.

There are other interesting or even crucial structural differences. In a capitalist society, surplus in the form of private profit is ultimately controlled and allocated by the owners of the means of production according to their principles of preference. In a socialist society, this function is performed by a central power, which takes care of the social goals of production through a general plan in such a way that no specific, or partial, plan reflecting the needs of a given region or industrial sector should contradict the priority list determined at the national level. Under modern conditions, planning is no exclusive prerogative of the socialist society. Capitalist societies, Western democratic

\footnotetext{
${ }^{15}$ C. Wright Mills, «The New Left», New Left Review, 5, Sept.-Oct. 1960, now in Power, Politics and People, New York, 1964, p. 249; see also «The Conservative Mood», op. cit., pp. 208-220.

${ }^{16}$ Cfr. R. Aron, ed., Colloques de Rheinfelden, Paris, 1960, esp. Part II ; and the remarks by Jeanne Hersch on Aron's Report ; cfr. Also J. Hersch, Idéologie et réalité, Paris, 1956.

${ }^{17}$ For a balanced comment on the ideological bias of present-day social scientists in this regard, see T. B. Bottomore, Classes in Modern Society, London, 1955; H. P. Bahrdt, Industrie-büroKratie, Stuttgart, 1958, passim. There is a host of criticism on the part of Soviet commentators about the so-called theory of a universal industrial society, post-capitalist and post-ideological; for a recent comment, see Zamoski in Kommunist.
} 
countries also are currently planning for economic development, especially for their underdeveloped areas, State intervention in the economic sphere is no longer a rare occurrence or an emergency measure. But it would be hasty and essentially incorrect, and it would probably amount to an «ideological lie», to infer a basic convergence between "capitalist society" and "socialist society" in the name of the logic of industrial development. More research is needed along lines, which can be only approximately indicated. Every country wants development and is ready to accept planning as a technique to achieve it. But Western democratic planning is largely indicative and sectional; it concerns those sectors which private enterprise does not seem to be able or willing to develop, usually because of scarce profit prospects; socialist planning is essentially nationwide; that is, global and rigid and tendentially coercive. The difference is a difference in kind, which has relevant social and cultural repercussions and points to a major ideological cleavage.

First of all, on manpower. Leaving aside the broader issue of political freedom and citizens' rights, even on the basis of a gross comparison between "capitalist» and "socialist» societies a major difference emerges with regard to the allocation of manpower system and the mobility of the work force. Actually, the whole problem of the optimal utilization of human resources is handled in a markedly different way. In a socialist society the existence of a nationwide plan articulated in smaller territorial and sectional plans, implies an effort of integration and coordination of all the productive resources, which makes for a drastic reduction of the options of individual employees. The transfer of employees from a factory to another or, even more, from one field of production to a different one, does not depend obviously on the personal feelings or ideological self-image of the employees themselves. It is strictly controlled by the explicit exigencies connected with the stated targets of the planning process. The system ensures the total employment of the work force available, but it does not touch upon personal preference and leaves aside the problem of motivation.

The contrast with a capitalist society is striking. Here the employee is relatively free to move around and to make his choice. The labour force will usually move and concentrate in certain areas where industry is booming, ready to move out and seek employment in other areas and in a different industrial sector according to the general economic trend and market opportunities. At the firm level, personnel management here involves a massive responsibility. Problems such as human relations within the firm and labour turnover related to the intrafirm competition for employees, especially for certain skills, represent by themselves major subjects for research and conceptual work on the part of industrial sociologists ${ }^{18}$.

\footnotetext{
${ }^{18}$ In an essentially political perspective, see the comparison attempted by Zbigniew Brzezinski and Samuel P. Huntington, Political Power: USA/USSR, Viking Press, New York, 1964. Criticism of the work of sociologists of industry as intrinsically manipulative is very common and not always well taken. The most recent and all-pervading attack is to be found in Herbert Marcuse, Onedimensional Man, London, 1964, which involves the Western societies as well as Communist world.
} 
These differences are real and empirically relevant. They are sufficiently perspicuous to explode any easy "theory» of convergence between the two systems, and they cannot be dismissed simply by saying that they are sectional in character ${ }^{19}$. Any social system tends to achieve a high degree of internal coherence whereby the reciprocal congruity of its component parts is assured. On the other hand, the rejection of the oversimplified theory of convergence as an end-product of an isomorphic tendency, which is supposed to be mechanically at work independently of systematic and ideological differences, does not mean that one should be blind to problems and situations, which seem to be common to any developing society and which can reasonably be taken as the outcome of what is being sometimes romantically referred to as the logic of industrialism ${ }^{20}$. Obviously, there is no abstract, timeless and placeless logic of industrialism. Industrial development is an historical phenomenon, the changing product of the concurrence of varying social forces in a given environment, which in each specific case should be identified, analyzed and possibly explained. Hasty attempts toward building a formal analytical model usually end up with a more or less sophisticated rationalization of ideological preference ${ }^{21}$. It is interesting to observe in this connection that in their effort to construct deductively an analytical model of the logic of industrialism a group of distinguished, American authors have simply forgotten to account for the existence of a politically organized and ideologically oriented labour movement in several countries, which are in a stage of transition from a predominantly agrarian economy to an industrial way of life. Such a conspicuous absence reduces sharply the usefulness of the model. Stressing the importance of consensus in society and the cult of efficiency per se, and regarding management as some sort of deus ex machina, they have mirrored the historical situation of the United States and they have unconsciously offered it as the necessary path or the inevitable blueprint for the newly developing countries ${ }^{22}$.

This is not to discount the validity of such attempts. They can be important and useful provided they do not «jump to conclusions», as it were, through the one-sided idealization of a given determinant or of an isolated factor which would supply, ex capite Jovis, a passe-partout explanation for everything. No matter how naïve, convergence theory has merit as a psychological symptom, as a testimony of the Zeitgeist ${ }^{23}$. It reflects a common, if disturbing, experience. Societies with a different historical background, endowed with contrasting legal and economic systems, institutional machinery and

\footnotetext{
${ }^{19}$ See in this connection the structures by Raymond Aron, on Maurice Duverger in R. Aron, «Société industrielle, idéologies, philosophie», Preuves, n. 167, Jan. 1965, esp. pp. 9-13.

${ }^{20}$ See, for instance, Clark Kerr, John T. Dunlop, Frederick Harbison, Ch. A. Myers, Industrialism and Industrial Man, Harvard Univ. Press, Cambridge, Ch. 2, «The Logic of Industrialism».

${ }^{21}$ For a redefinition of the belief that industrialization operates predominantly to undermine traditional societies, see $\mathrm{H}$. Blumer, «Industrialization and the Traditional Order», Sociology of Social Research, 48, 2, Jan. 1964, pp. 129-138.

${ }^{22}$ Clark Kerr, John T. Dunlop, Frederick Harbison, Ch. A. Myers, op. cit., pp. 42-44.

${ }^{23}$ Interesting in this connection is Cyril A. Zebot, The Economics of Competitive Coexistence - Convergence through Growth, New York, 1964.
} 
value-orientation, appear to show increasingly analogous behavioral patterns as they adopt similar technological processes.

In order to distinguish one society from another, in particular a "socialist» society from a "capitalist» society, structural differences, concerning the formal codification of individual and group behaviour as sanctioned by the legal system of a given country or bloc of countries, are necessary but not sufficient. Their insufficiency in this respect emerges with full evidence when we take into consideration, beyond the letter of laws and regulations and of ideological platforms, the actual day-to-day routine of social life, the specific daily instances of power allocation and the practical exercise of it, the concrete possibility of social equality and of individual and group mobility, the quality of the average relationship between citizen and institution. In other words, contrary to the passionate expectations of one century of ideological struggle, socialization of the means of production and exchange does not automatically produce socialization of power; it does not automatically lead to a social situation in which rational administration of things replaces domination over human beings and eliminates the inevitable consequences of such domination - preferential monetary rewards, a higher prestige, a higher ability to spend and to indulge into honorific consumption, a privileged position with regard to career pattern and social status for some restricted social groups. Under present-day conditions, terms such as «capitalist» or «socialist» society appear to be essentially inadequate unless one clings to the «vulgar» conception of Marxism whereby to a given structure, or Unterbau, of society would axiomatically correspond a given ideology and a personality structure, the famous "new man", endowed with special values and incentives, who is, however, nowhere to be seen. These formulas belong to the nineteenth century world of the Weltanschauungen and they are not likely to contribute substantially to the advance of our knowledge of present-day society. It is difficult on their basis to assess how, and how far, the impact of the technological frame affects culturally and structurally different societies, which share the fact of having chosen the technical process and the machine discipline as an important instrument of their self-development.

Technical process, once adopted and applied to industrial production on a large scale, appears to be capable of social and human consequences, which are far-reaching in scope and relevant in nature as they concern the prevailing type of personality, its main value orientations and its expectations, the structure and function of the family and of the small work group and the basis for the legitimation of the relevant economic and political decisions. Any industrial manager, no matter in which society he is active, or whether he is a fully professional manager or a manager owner or co-owner of the business enterprise, or finally a public functionary with managerial prerogatives, acts in his managerial capacity according to a pattern in which four major steps are perfectly visible: information, decision, action, control. In a broader perspective, one may point 
to certain common features, which seem to belong to any industrially advanced and technically developed society, be it socialist or capitalist, democratic or totalitarian, pluralistic or highly centripetal. There are general characteristics which seem to bind together modern societies, and which are perhaps responsible for an uncritical use of the notion of modernization. Without forgetting or blurring structural differences, ideological cleavages and historical background, the process of industrialization seems to provide a meeting ground for quite different countries, as for years Raymond Aron has tried most eloquently to show ${ }^{24}$. But Wilbert Moore and Arnold Feldman have correctly criticized the simplifications which are now current in this respect ${ }^{25}$. Certainly the notion of the decline of ideological enthusiasms does not seem to be applicable to the developing countries, as Shils had noted since 1955, and Bell himself recognizes the existence of nationalistic ideologies typical of African and Asian countries today, but he quite readily points out that they do not entertain the universalistic and cosmopolitan character of their European XIX century counterparts ${ }^{26}$.

\section{The cultural foundations of the industrial societies and the classical analysis of the ideology of industrialism}

There is no dearth of general studies of the "cultural foundations» of modern or industrial societies, both East and West, but we are far from have anything approaching a plausible well-rounded analysis of the ideology of industrialism in the tradition of the classical legacy of Smith, Saint-Simon, Marx and Weber.

The gap concerning the place and role of ideology in the process of industrialization and the ideological attitude of the actors of that process is certainly a serious one. Despite different historical heritages and institutional setups, interesting convergences could probably be established as regards such major functions as entrepreneurship, labour commitment to industrial employment, and so on. A few attempts made to relate systematically a certain personality type to a given set of structural traits of the social system through the mediation of the prevailing habits of thought and value-orientations have ended in the lamentable confusion between analytical framework and specific historical content (see notably Neil J. Smelser, Social Change in the Industrial Revolution - An Application of Theory to the British Cotton Industry, 1770-1840, Chicago, 1959). Notable contributions in this respect are the work of Reinhard Bendix (Work and Authority in Industry - Ideologies of Management in the Course of Industrialization, New York, 1956), and, with a widely different approach, of Francis X. Sutton, Seymour E. Harris, Carl Kaysen, James Tobin (The American Business Creed, Cambridge, 1956), David Mc Clelland (The Achieving Society, New York, 1961), not to mention the breezy impressionistic portraits, stimulating, however, from a comparative point of view, by

\footnotetext{
${ }^{24}$ See, for some more nuancé restatements, R. Aron, Dix-huit leçons sur la societé industrielle, Paris, 1962.

${ }^{25}$ Cfr. «The Sociology of Development» in Transactions of the Fifth World Congress of Sociology, ed. ISA, Louvain, 1962.

${ }^{26}$ With regard to contemporary nationalistic ideology, see the interesting article by R. Girardet, «Autour de l'idéologie

nationaliste: perspective de recherches», Revue Française de Science Politique, XV, 3, Juin 1965, pp. 423-445.
} 
David Granick (The European Executive, New York, 1962; The Red Executive, New York, 1960) ${ }^{27}$. Employees have been studied from various standpoints, usually in terms of their society image (like in Popitz and associates) or value orientation (as in Ely Chinoy with regard to the USA automobile workers ${ }^{28}$ ) and in terms of the personal and professional repercussions if the evolution of industrial machinery (A. Touraine, A. Pizzorno, S. Mallet). The structure of authority at the plant level has been explored from the ideology point of view by Polish sociologists (A. Matejko, A. Sarapata, H. Kowaleski, and others). The very concept of class still entertains the attention of French sociologists (see their meeting in Quebec, 1964, with R. Aron, "class as representation and will» (Ia class comme représentation et comme volonté). One should also mention $\mathrm{M}$. Kaplan, editor, The Revolution in World Politics, New York, 1962, and a number of European contributions related, rather scholastically, to the debate on Marxism, such as J. Habermas, Theorie und Praxis, and L. Sebag, Marxisme et structuralisme. Perhaps more rewarding are some studies of an historical nature: Rudé, The Crowd in History, New York, 1964, a study of political demonstrations and aggressive mob behaviour in France and England during the years 1730-1848; Hill, The Intellectual Origins of the English Revolution; MacPherson, The Political Philosophy of Possessive Individualism; and Thompson, The Making of the English Working Class.

With regard to the specific problem of modernization and of the function of ideology in the developing countries, an outstanding contribution is the already mentioned Ideology and Discontent edited by David E. Apter and including studies by Leonard Binder (Egyptian and Islamic nationalism), Robert Scalapino (modern Japanese political thinking), Philip Converse (American public and politics) and others. Here it seems that the category "modernization" is used monodically to cover widely different historical contexts and ideological meanings. This is particularly evident in the essay by Scalapino. Clifford Geertz, dealing with ideology as a cultural system, appears to be much more articulate and actually takes into consideration also what could prove to be the most important aspect of ideology that is its meaning as a particular linguistic structure. No mention is made in this connection of the work of Claude Lévy-Strauss, but Geertz refers to Kenneth Burke without, however trying to test the heuristic validity of Burke's notion of terms as having «entelechial» implications because language contains within itself a "principle of perfection ${ }^{29}$.

Whereas Apter develops, in a lively and quite interesting manner, his main idea that ideology is somehow related to the ability or inability of a given society to satisfy the emulative ambition and its drive which, according to him, is present in every human being (if not a reedition of Thomas' four wishes theory, revised and perhaps simplified, this notion could appear as nothing more than a projection of American

\footnotetext{
${ }^{27}$ See the critical comment to D. Granick, The Red executive - A Study of the Organization Man in Russian Industry, by V. Drobizhev, "On the Role of USSR Working Class in Supplying Executive Personnel to Socialist Industry», Istorüa SSSR, 4, April 1961.

${ }^{28}$ E. Chinoy, Automobile Workers and the American Dream, New York, 1955.

${ }^{29}$ See esp. K. Burke, The Rhetoric of Religion - Studies in Logology, Berkeley, $1961 .$.
} 
values on other societies and on different cultural settings), the concluding chapter of R. Bendix is, on the contrary, quite sensitive to the historical perspective and gives a useful account of the evolution of the concept of ideology. In connection with the problem of modernization, together with the reedition of The Passing of Traditional Society, by Daniel Lerner, a mention should be made of The Urban Process (New York, 1964), by Leonard Reissman, in which the author sees among the main components of modernization and urbanization the rise of nationalism as the dominating and unifying ideology, but the problem of the indicators for such components cannot be said to have been adequately solved, mainly because of lack of cross-cultural studies and in general because of missing data.

\section{The end-of-ideology thesis and the theorization of a post-ideological age}

Meynaud, Mills, and the other critics of the end-of-ideology thesis react quite vivaciously to the derogatory connotation of the term «ideology» which is at least implicit in any attempt to theorize a post-ideological age.

This is, however, a thoroughly familiar problem. One could contend that the whole history of the sociological analysis of ideology can be seen as an attempt to answer the question of how and on the basis of what criterion any given form of thought can evade the charge of being ideological. This question looms large and appears closely connected with the fact that the elusive problematic nature of ideology involves the sociological study of ideology itself. In other words, sociological conceptual frameworks and techniques are themselves relative to their own specific social and cultural contexts and have no basis for claiming a status of invariance or absolute objectivity in the sense of the natural sciences. In this perspective, the work of Marx is the obvious starting point for the sociological study of ideology. And even before Marx, Comte sets for himself the task of criticizing the competing ideologies of his time as radically inadequate to effect the necessary "social reorganization" and actually responsible for the intellectual confusion and anarchy of the day. Comte's attack is aimed simultaneously at three targets: the revolutionary ideology, which aims at progress, but still on the basis of metaphysical preconceptions; the reactionary ideology, which wants at all costs to maintain the status quo and is therefore intimately contradictory: and, finally, the constitutionalist ideology because of its formal character, which makes it incapable of satisfying the two basic needs of society - those of order and progress ${ }^{30}$.

Comte's critique cannot, however, be regarded as an anticipation of Marx's demystification of the "German ideology". Marx's position is much more problematic and does not justify any interpretation in mechanistic terms. For Marx history is manmade and men are moved by ideas, to be sure not in vacuo but within specific contexts. In order words, the theory of the material conditioning of ideas does not exclude their

${ }^{30}$ A. Comte, Cours de philosophie positive, ed. J. B. Baillière et Fils, Paris, 1864, vol. IV, p. 87. 
importance, their Umwälzende Praxis (see in this connection Barth, Wahrheit und Ideologie). For Marx and Engels ideologies correspond to the need of man to understand nature and his social environment; this need is satisfied by different social groups in a different way. Thus, ideologies are, on the one hand, super structural productions and, on the other, distorted points of view, that is ideas that pretend to be of universal value while reflecting a sectional interest or class positions. In this sense, it is possible to regard Marx as the founder of the sociology of knowledge ${ }^{31}$.

But Marx's conception of ideology is hardly understandable, as Birnbaum aptly points out, without explicit reference to the interrelated concepts of alienation, mystification and reification. A mechanistic notion of Marxism, for all its naiveté, can be politically expedient, as Antonio Gramsci has shown, to the extent in which it reinforces in the political activists the belief in the final victory. It is in the nature of a religion of the oppressed, a chiliastic promise. As regards the private, ideological myths fabricated by intellectuals without any reference to the social context or the political struggle, it is obvious for Gramsci that they are only idle vues de l'esprit, "lorianesimo", that is, an expression of intellectual irresponsibility.

There has been recently a revival of interest in the concept of "alienation» which has become a popular term to indicate any kind of subjective or objective maladjustment, but one can easily detect in most studies an uncritical reduction of the term to its existential, that is vaguely psychological, meaning which appears to be by definition beyond verification. The term should be first of all clarified in all its current meanings, and the use of it for social research should be critically tested. Certainly one cannot dispute a priori the value of speculative considerations of alienation; the sociological determination and research of the phenomenon, however, are something different. Works such as the ones by J. Habermas (Theorie und Praxis) or H. Marcuse (One-dimensional Man) are certainly guided by a genuine concern with grasping the problem globally as a totality; the danger remains that dialectical impatience with empirical data and analytical research might simply lead to a merely verbal totality, that is, to a totality which is empty and which only in the case of J. P. Sartre, despite his typically nineteenth century equivocal terminology (see for instance «Le Patron...», «l'Ouvrier...» in the Critique de la Raison dialectique), could probably be saved on account of its literary suggestiveness.

In this respect, the effort made by Melvin Seeman is important at least so far as the distinction between the concept of alienation and other related concepts, such as 
self-estrangement, rather loosely used by Fromm and others, is concerned ${ }^{32}$. Basically, alienation means a loss and an exclusion - but of what and from what, and with respect to whom and whose aspirations? This determination in terms which should be more specific that the broad, philosophical category of alienation is essential to sociological analysis. Unfortunately, this preliminary determination is usually not made explicit in most research dealing with alienation of individuals and groups. Usually both environmental conditions and culture, that is objective situations, and individual or group interests and values, that is subjective data, are inadequately defined and a restrictive concept of alienation as «individual feeling of uneasiness» emerges as almost inevitable ${ }^{33}$. In general, one could conclude that the use of the term alienation should be discouraged as regards sociological analysis.

\section{The evolution of Marx's concept of ideology}

It would certainly be of interest to follow through the evolution of Marx's concept of ideology with its correlates (alienation, reification and mystification) centring the attention on the work of Lukács seen, as Lichtheim suggests, as a mediating link between Weber and Mannheim.

But we must content ourselves with sketchy indications. Marxian categories can be very useful, as generally en-enriching factor as well as a source of heuristic insights, provided they are no longer taken and dealt with as philosophical concepts. They must be translated, as it were, into specific research tools, that is to say into operational concepts. We have seen that Melvin Seeman, for instance, has broken down the concept of alienation, which has in Marx a characteristically philosophic usage, into five sociologically relevant categories (powerlessness, meaninglessness, normlessness, isolation and self-estrangement). These categories constitute a step forward and are necessary, but not sufficient. The structure of sociological explanation requires not only general categories but in the first place definite sets of terms and propositions specifically related to the phenomena to be explained or understood. This seems to be an essential prerequisite if one is to avoid the curious and all too frequent confusion between the construction of social theory and a purely mechanical model-building ability.

\footnotetext{
${ }^{32}$ Cfr. M. Seeman, "On the Meaning of Alienation», The American Sociological Review, XIV, 1959, pp. 783-791; attention to the «rediscovery» of alienation not only in the United States was called, with his extraordinarily sensitive ear for intellectual fad, by Daniel Bell. Vittorio Rieser has pointed out that during the years 1936-1955 not one article on alienation was published in The American Sociological Review; since 1956, there seems to be a growing interest in this subject on the part of all the social science journals; see V. Rieser, "Il concetto di alienazione in sociologia», Quaderni di Sociologia, XIV, 2, aprile-giugno 1965, p. 156; cfr. also, Joseph Gabel, La Fausse Conscience, Paris, 1962. For "alienation» as meaninglessness of social culture, paving the way to totalitarian experiments, the classic work is Th. W. Adorno and associates, The Authoritarian Personality, New York, 1950.

${ }^{33} \mathrm{Cfr}$. for instance Jan Hajda, «Alienation and Integration of Student Intellectuals», The American Sociological Review, XXVI, 1961, pp. 758-777; also D. G. Dean, «Meaning and Measurement of Alienation», The American Sociological Review, XXVI, 1961, pp. 753-757; for an exception, although methodologically inadequate in some respects, see G. Bonazzi, Alienazione e anomia nella grande industria, Milan, 1963.
} 
Berger and Pullberg have successfully subjected to an analogous treatment the Marxian category of reification, which they conceive as the moment in the process of alienation in which the characteristic of thing-hood becomes the standard of objective reality ${ }^{34}$. In fact, they argue that, if socialization has been only to an extent successful, then the individual acts within the socially prescribed channels with a minimum of reflectivesness. That is, he is integrated. But such integration is never complete and für ewig, as utopian social systems, which pay for their perfection the high price of immobility, would have $i^{35}$. Alienation and sociation are in reality linked processes. Human beings are both historical and meta-historical. At the very moment in which they perceive themselves and their destiny as purely historical, their ideologies, that is to say the meaning-systems supporting their day-to-day behaviour and giving sense of direction and purpose to their daily experience, are likely to go to extremes, to become «mad virtues» which have lost everything except the ability to abstract reasoning ${ }^{36}$.

In this sense, sociology itself is involved and its relationship with ideology forces it to clarify its own position and orientation. Berger and Pullberg point out that «sociology has the tendency either to be a narrow empiricism oblivious of its own theoretical foundations or built highly abstract theoretical systems emptied of empirical content. Both these directions take sociology away from that everyday life which is supposed to be the subject of the discipline. Sociology too is super-structure [...]. That is, sociology is grounded in the pulsating inter-subjectivity of the real world of men. The de-humanization of sociology in either of the above-mentioned directions not only results in a pomposity as abstruse as anything the philosophers might conceivably produce, but marks the point at which sociology has lost its own subject ${ }^{37}$. These points, which have been made by several scholars and have become almost popular, should not be understood as a plea against the diversity of themes and of approaches to the study of human problems and social situations. Especially in the case of $C$. Wright Mills, it seems that his distinction between «individuals and private milieux», as being unworthy of the study of «intellectual workers», and «structures» or "larger issues», as a proper study object for the sociologist, is too sweeping and fundamentally biased $^{38}$. It betrays the nearly total absence of that enlargement of vision which comes

\footnotetext{
${ }^{34}$ Cfr. Peter Berger and Stanley Pullberg, "Reification and the Sociological Critique of Consciousness», History and Theory, IV, 2, 1965, pp. 196-211.

${ }^{35}$ On the concept of system, for a strong and well-taken emphasis on its character of «social myth... (giving) the individuals a sense of being integrated into something stable and supportive», see Alfred McClung Lee, "The Concept of System», Social Research, 32, 3, Autumn 1965, pp. 229-238.

${ }^{36}$ See in this respect the remarks by Albert Camus, L'homme révolté, Paris, 1951. Camus denies that man's nature is totally historical, but on the other hand he admits that whatever man does is bound to be historical; there is no evasion from history; Camus' critique of modern ideologies as ignoring the Greek ideal of «measure» ( $\mu \varepsilon \delta \varepsilon v$ á $\gamma \alpha v$ ) is suggestive, but his reduction of Aeschylus to some sort of disciple of Edmund Burke is less convincing. See also Richard H. Cox, «ldeology, History and Political Philosophy Camus' L'Homme Révolté», Social Research, 32, 1, Spring 1965, pp. 71-97.

${ }^{37}$ P. Berger and S. Pullberg, cit., p. 211.

${ }^{38}$ See especially C. Wright Mills, The Sociological Imagination, New York, 1959; passim; in this respects, at least, Mills shows a lack of imagination.
} 
with a sense of the manifold ways in which intelligence can be exercised, the sense of the variety of forms both morality and intelligence can take in the life of the mind. This is not said to convey the idea that everything goes provided it delivers results. There are profound qualitative differences both in method and in substance, which make for a contrast between a dialectically oriented sociology and sociological studies empirically and analytically inclined ${ }^{39}$. But the necessity for a critical determination of the concepts to be used in sociological research is certainly common, especially as regards the concept of ideology and its correlates. As the efforts by Melvin Seeman and Berger seem to demonstrate, this is a fruitful approach and one which could perhaps be used in a critical reinterpretation of such authors as Karl Mannheim and Vilfredo Pareto who could be see essentially and, in my opinion, correctly, as critics of ideological thinking and attitude.

In the case of Mannheim, his distinction between ideology and utopia would probably reveal its purely formal character and some of the major shortcomings of his position would become apparent, in particular that peculiar petitio principii of his consisting in positing as a general postulate the existential determination of knowledge, quod erat demonstrandum. The postulate that every rationale is of necessity an ideology puts him in a difficult position and the strictures of Gustav Bergmann are well taken: «If this proposition that every rationale is an ideology is itself objectively true, how can he know it? If it is not, why should we pay attention to it? And what in particular is the value of a social science thus construed? ${ }^{40}$ ". The answer of Mannheim is known: in a stratified society intellectuals enjoy some sort of extra-territorial immunity, as it were; they do not belong to any social class in particular: actually they circulate rather freely among the various social groups, they tend to be more broadminded than the average, and by this very fact they are in a position to see the distorted ways of thinking of other people and explain them away. It would be difficult to prove this point having resort to specific research. Studying Veblen's career, thinking and attitude, Walter P. Metzger has demonstrated, or has at least argued plausibly, that «however he (Veblen) may have seen himself, Veblen's social goal was to weave the latent evolving attitudes of his group into an ideology that would attract adherents and compel attention ${ }^{41}$. In fact, "as a disabused intellectual he lashed out at the tenets of the dominant ideology: at the nationalistic pretensions that fettered the free flow of ideas, at the invidious aping of leisure class manners that puts a premium on material display and useless information. As an isolated intellectual, he rejected farmer, small businessman and worker as not possessing the qualities of mind necessary to effect beneficial changes. It is probable that Veblen in his own mind was not aware of the ideological function he

\footnotetext{
${ }^{39}$ For a clear restatement of such differences, see Jürgen Habermas, «Gegen einen positivistisch halbierten Rationalismus Erwiderung eines Pamphlets», Kölner Zeitschrift für Soziologie und Sozialpsychologie, XVI, 4, 1964, pp. 635-659; it is a rebuttal to the article by H. Albert, "Der Mythos der totalen Vernunft», which had appeared in the n. 2 issue of the same Journal.

${ }^{40}$ Cfr. G. Bergmann, cit., p. 213.

${ }^{41}$ Cfr. Walter P. Metzger, «Ideology and the Intellectual: a Study of Thorstein Veblen», Philosophy of Science, 16, 1949, p. 133.
} 
performed. [...] The transformation of the group's need into the individual's thought is a subtle process not always known to the thinker ${ }^{42}$.

This kind of analysis would probably yield more copious results than the speculative elaborations about the "total» conception of ideology which Mannheim develops at length and which does not seem to amount to anything different from the opposition between ideology and the sociology of knowledge, that is to say between the distorted view of a specific content and the distortion of methodological framework and concepts. It would be, at any rate, difficult to deny any ground to the disappointment voiced by K. Danziger: "Since the publication of Mannheim's major contributions to the sociology of knowledge the discrepancy between their epistemological promise and their actual fruit in terms of empirical research has become more and more striking» ${ }^{43}$.

The importance of Mannheim's contribution exceeds, however, the scope of methodological considerations, as Kurt $\mathrm{H}$. Wolff has amply demonstrated in his excellent introduction to the selected writings on "sociology of knowledge» ${ }^{44}$. His seminal ideas on scientific politics and democratic planning and on the role of the social sciences as potential «policy sciences» are well known and go a long way beyond Lukács standpoint that the knowledge that a being has of himself is not science but consciousness, contrary to the opinion put forth by L. Goldmann ${ }^{45}$.

It is in Pareto that we have the pure opposition between science and ideology. In this sense, that is as a critic of ideological thinking, it seems correct to place Pareto side by side with Marx; they both try to "unmask», to see what lies behind the «ideological superstructures", that is behind the "derivations» with which people rationalize their instinctual drives and their special interests ${ }^{46}$. But the ideological preferences underlying the "scientific» thinking of Pareto himself have been keenly examined

\footnotetext{
42 Ibidem. The problem of the intellectual in an industrial society as of a man threatened by technological unemployment due to the growing specialization of the social functions has attracted considerable attention with highly uneven results. Cfr. William MacDonald, The Intellectual Worker and his Work, New York, 1924; R. Williams, Culture and Society, London, 1958; Jean Touchard, editor, "Les intellectuals dans la société contemporaine», Revue Française de Science Politique, déc. 1959; N. Bobbio, Politica e cultura, Turin, 1955; G. B. De Huszar, ed., The Intellectuals - a Controversial Portrait, Glencoe, 1960; R. Williams, The Long Revolution, London, 1961; Lewis A. Coser, Men of Ideas, New York, 1965.

${ }^{43}$ K. Danzier, «Ideology and Utopia in South Africa: a Methodological Contribution to the Sociology of Knowledge», The British Journal of Sociology, XIV, 1, March, 1963, p. 59.

${ }^{44}$ See K. Mannheim, Wissenssoziologie, Berlin and Neuwied, 1964; Introduction by Kurt H. Wolff, "Karl Mannheim in seinen Abhandlungen bis 1933», pp. 11-65.

${ }^{45}$ L. Goldmann, Sciences humaines et philosophie, Paris, 1953, p. 29 ; see also, F. Leonardi, "Sociologia della conoscenza e pianificazione sociale», Rassegna Italiana di Sociologia, I, 2, April-June 1960, pp. 25-44; R. Treves, «Interpretazioni sociologiche del fascismo», Occidente, 6, 1953, pp. 371-391; E. S. Bogardus, "Mental Processes and Democracy», Sociology and Social Research, 41, Nov.-Dec. 1956, pp. 125-132.

${ }^{46}$ See esp. N. Bobbio, «V. Pareto e la critica delle ideologie», Rivista di Filosofia, 1959, pp. 355 ff.; for a recent reappraisal, James H. Meisel, editor, Pareto and Mosca, Englewood Cliffs, 1965; G. Eisermann, Vilfredo Paretos System der allgemeinen Sociologie, Stuttgart, 1962; for a descriptive examination, see Morris Ginsberg, "The Sociology of Pareto», The Sociological Review, XXVIII, 3, July 1936, pp. 221-245.
} 
and made explicit, especially with regard to the elaboration of the concept of «élite» and "élite circulation", by Thomas B. Bottomore ${ }^{47}$. The methodological weaknesses of Pareto, on the other hand, have been quite effectively handled by Werner Stark ${ }^{48}$. It would be interesting to see how much of Pareto's thinking about «ideologies» a term which never appears in the Trattato di Sociologia generale, but which could be properly used for all those forms of non-scientific theories presenting in a highly theoretical or abstract jargon moral and political programs - has been taken over by Talcott Parsons. It seems that the parsonian distinction between ideas, or beliefsystems, of an empirical character and of a non-empirical character reflects the distinction that Pareto draws between theories which transcend and theories which do not transcend experience. For Pareto the experience-transcending theories are by definition pseudo-theories, that is theories non-scientific and devoid of any cognitive value; they are programs of action, not tools of knowledge. Parsons, on the contrary, does not exclude the cognitive value of meta-empirical or non-empirical theories. Thus, ideology becomes in Parsons an important instrument of «justification» and "legitimation» of change in the institutional structures to insure a norm-directed integration of the community. The connection between value and ideology is therefore of fundamental importance ${ }^{49}$.

But the problem with the social theory of Parsons is well known: there is no place in it for conflict and change, the emphasis and the attention of the writer being absorbed by the classical issues of order and integration in society (consensus; social contract).

\section{The ideological thinking and acting}

Specific studies of ideological thinking and acting are growing in number and the areas of empirical study of ideology (such as the special outlook and orientation of class positions within the social structure and occupational groups, political activities and organizations in the developing countries and in the advanced industrial societies, intellectuals and student culture, mass communication, personality motivation) seem to be practically limitless ${ }^{50}$.

But there is a price for this varied landscape. The term "ideology" is used in a shifting and imprecise way. As such it points to something sociologically amorphous and, from a research point of view, it becomes useless if not misleading.

\footnotetext{
${ }^{47}$ See T. B. Bottomore, Elites and Society, London, 1964, esp. Ch. I, «The Elite: Concept and Ideology», pp. 1-17.

${ }^{48}$ Cfr. W. Stark, «In Search of the True Pareto», The British Journal of Sociology, XIV, June 1963, pp. 103-112.

${ }^{49}$ For the ideological implications of the parsonian position, see Andrew Hacker, "Sociology and Ideology», in Max Black, editor, The Social Theories of Talcott Parsons, Englewood Cliffs, 1961, pp. 289-310.

${ }^{50}$ See for instance, H. McClosky, "Consensus and Ideology in American Politics», The American Political Science Review, LVIII, 2, 1964, pp.361-382; J. P. Huntington, "Conservatism as an Ideology», The Am. Pol. Sc. Review, LI, June 1957, pp. 454-473; R. E. Lane, Political Ideology, New York, 1962; V. K. Dibble, "Occupations and Ideologies», The Am. Journal of Sociol., LXVIII, 2, Sept. 1962, pp. 229-241; F. W. Howton, B. Rosenberg, «The Salesman: Ideology and Self-imagery in a Prototypic Occupation», Social Research, Autumn 1965, 3, pp. 277-298; S. M. Lipset, "University Students and Politics in Underdeveloped Countries», III, 1, 1964, pp. 15-56.
} 
Omnis determinatio nulla definitio. At times ideology seems to be simply equated with ideas and ideals, as a moving historical force. At times it amounts to nothing more than a manipulative device to win and structure the loyalty and to mobilize the energy of masses of human beings. It is quite natural that for the sociologists, to indulge in a bon mot, it all depends whether they have their revolution in front or in back of them. Correspondingly, ideology can be regarded either as a merely mystifying mask or as an official doctrine which reveals the true direction of historical development. A suggestive field of study for sociologists who are not a priori either pro-Soviet or pro-American could be the attempt to detect the factual propositions in the ideological systems or doctrine, to identify the relatively permanent characteristics of ideological groups and organizations, to understand and to spell out the conditions making for the development of ideological thinking and conduct, and finally to outline the eventual functions of sociology with respect to ideology.

Not much has been done along these lines. Frederick M. Watkins has pointed out three characteristic features of modern ideology, namely optimism, oversimplification, and belief in progress. In general, he sees ideology as essentially connected with the breaking down of the traditional political and social order as a means to face the unprecedented problems and opportunities posed by an age of growing mass participation in politics ${ }^{51}$. The mobilizing and militancy aspect of ideologies is also stressed by Carl J. Friedrich as essential. According to Friedrich, ideologies are action-related systems of ideas. From this point of view, ideologies are not only setting goals; they imply also the necessity of an organizational structure to reach them and the elaboration of a strategy and a tactics for practical action to implement them. Friedrich criticizes the indiscriminate use of the term ideology in its broad connotation: "It is confusing and fails to provide the opportunity for political analysis to call any system of ideas an ideology, such as the philosophy of Aristotle or the theology of the Old Testament. Such systems may provide the basis for an ideology, but only after being related to action in a specific sense and for a specific situation $»^{52}$.

But how does ideology finally emerge? And what are the characteristics of specifically ideological groups? Can they be subsumed under the traditional label of primary, face-to-face groups, characterized by a high degree of internal cohesion and close personal feelings of the Gemeinschaft variety, or should they be dealt with in their own terms?

Accounts of the rise and subsequent development of ideological movements show the tendency to personalize the issues through the emphasis on the charismatic qualities of

\footnotetext{
${ }^{51}$ Frederick M. Watkins, The Age of Ideology, Englewood Cliffs, 1964, passim.

${ }^{52}$ Carl J. Friedrich, Man and his Government - An Empirical Theory of Politics, New York, p. 89, italics in the text. See also Carl J. Friedrich, Totalitarian Dictatorship and Autocracy, Cambridge 1956, esp. Ch. III, «The Nature and Role of Ideology».
} 
the leaders ${ }^{53}$. As regards the specific characteristics of ideological groups, sociological analysis seems in the main still confined to the usual and mostly mechanicistic dichotomies Gemeinschaft versus Gesellschaft, structure versus motivation, personal versus functional, and so on, as if social process would develop and move like a train on its railways tracks from one station to the next one. In this connection, the pioneering effort by Vladimir C. Nahirny has a special relevance ${ }^{54}$. Refusing to throw everything into the logically exclusive categories mentioned above, Nahirni tries in fact to identify the basic components of ideological orientation and to show how they differ from personal and functional ones. In the first place, ideological orientation is total; secondly, it is dichotomous; thirdly, it precludes seeing an individual as a composite of personal ascribed qualities and performances, and finally, in the fourth place, ideological orientation precludes a direct affective disposition toward human beings. The translation of these components into empirically relevant propositions, difficult as it is, would indubitably result in a set of more refined tools for social analysis.

\section{The study of an ideological system in action by analysing the relationship between ideology and sociology}

It would be interesting at this point to study an ideological system in action through a detailed analysis of the relationship between ideology and sociology in the Soviet Union.

In fact, here perhaps more directly than anywhere else ideology faces its experimentum crucis, and the limitations of ideological dogmatism, when confronted with the problems of day-to-day administration and the realities of power, become apparent. Not to mention the intrinsic difficulty, the introductory nature of these remarks makes us a content with some very general indications.

The slow, uneven and generally difficult development of sociology in the Soviet Union and in other Eastern European countries is a well-known fact which goes back to the government decree of 1922 on the basis of which sociology, hardly accepted into the academic world with the February Revolution, was again excluded from the universities, with the exception of the chair of sociology at the University of Moscow which lasted until $1924^{55}$. The process of transformation of traditional sociology into the Marxist-Leninist «scientific» sociology has been recently described by Henri Lefebvre

\footnotetext{
${ }^{53}$ Cfr. Barrington Moore, Jr., Soviet Politics - The Dilemma of Power, Cambridge, 1950, esp. Part One, Ch. I, «How an Ideology Emerged".

${ }^{54}$ Vladimir C. Nahirni, "Some Observations on Ideological Groups», The American Journal of Sociology, LXVII, 4, January 1962, pp. 397-405.

${ }^{55}$ For accounts about pre-Soviet sociology, see H. Becker, and H. Barnes, Social Thought from Lore to Science, New York, ed. 1961, vol. III, pp. 1029-1059: also, for Soviet Sociology, see the chapters on «Russian Sociology» in G. Gurvitch, and W. E. Moore, eds, Twentieth Century Sociology, New York, 1945, J. Roucek, ed., Contemporary Sociology, New York, 1958; for the populistic background and Russian traditional sociology, see J. Hecker, Russian Sociology. A Contribution to the History of Sociological Thought and Theory, New York, 1934.
} 
who does not, however, take into consideration pre-Revolution sociology and sees the beginning of the involution with Stalin's advent to power ${ }^{56}$. Stalin's political apparatus, which successfully replaced the old-time militants with State bureaucratic, certainly played a decisive role, especially crucial in the days of the personality cult, but the transition and the final conversion of sociological analysis into the Diamat were made possible, much earlier, by the work of Plekhanov and by Lenin's concept of the revolutionary party with its typical priority of action theory over and against theory-reality ${ }^{57}$.

The thesis put forward by $\mathrm{H}$. Lefebvre does not contradict the official position taken at the present time by Soviet sociologists. According to G. Osipov and M. Yovchuk, it is true that the personality cult of Joseph Stalin slowed down the progressive advancement of concrete social research in some measure in the Soviet Union. The program of social research outlined by these authors is quite impressive and touches on the following problems:

1) The alternation of the social, structure of society in the process of building Communism;

2) Modifications in the character of work;

3) The transfer of Socialist State functions to public self-governing organizations;

4) Soviet family life and functions in relation to living space and material and social conditions;

5) The spiritual life of the people and the maximum development of personality ${ }^{58}$.

There is no doubt that on some of these topics a broad convergence of research interests could materialize as regards both Soviet and Western Sociology. Equally definite is the fact Soviet sociologists tend to view Western non-Marxist sociology through the coloured glass of ideological dogma, but the very progress of Soviet society makes it compulsory to adopt non-ideological research techniques and to go to the empirical facts of life if nor no other reason than to satisfy, through timely, circumscribed and reliable information and data, the need to control the occurring

\footnotetext{
${ }^{56}$ Cfr. H. Lefebvre, "Les cadres sociaux de la sociologie marxiste», Cahiers Internationaux de Sociologie, XXVI, Jan. 1959.

${ }^{57}$ About the Diamat, for a Western comment see G. Wetter, Der Dialektische Materialismus, Freiburg, 1952; J. Bochenski, Der Sowietrussische Dialektische Materialismus, Berne, 1950; Die Dogmatischen Grunlagen der Sowietischen Philosophie, Dordrecht, 1959; for a recent contribution on Lenin, see A. Meyer, Leninism, New York, 1962; see also the review of this book by S. Vishievsky, in Pravda, May 23, 1963, p. 3. For general recent contributions, see Zbigniew K. Brzezinski, Ideology and Power in Soviet Politics, New York, 1962, esp. Ch. 3, "The Nature of the Soviet System», and Ch. 4, "Communist Ideology and International Affairs»; John A. Armstrong, Ideology, Politics and Government in the Soviet Union, New York, 1962.

${ }^{58}$ See G. Osipov, M. Yovchuk, "Some Principles of Theory, Problems and Methods of Research in Sociology in U.S.S.R.», American Sociological Review, 28, 4, August 1963, pp. 620-623.
} 
social and cultural changes ${ }^{59}$. In this connection, especially as regards the autonomy of sociological analysis, which should not be definition subordinate to ideological dogma, some interesting dissenting opinion has been voiced among Soviet social scientists $^{60}$. But the evolution from ideology as a mobilizing instrument to ideals as a shared conscious heritage indicates a long and difficult process whose final success rests on the ability and willingness, East and West, to face each issue and situation with intellectual clarity and free from artificial pessimism or optimism ${ }^{61}$.

\section{Bibliography}

1. Franco Ferrarotti, L'énigme D'Alexandre, Bruxelles, La Lettre Volée, 2004.

2. Franco Ferrarotti, Social Theory for Old and New Modernities: Essays on Society and Culture 1976-2005, Lanham, Boulder, New York, Oxford, Lexington Books, 2007.

3. Franco Ferrarotti, La société et l'utopie, Bruxelles, La Lettre Volée, 2008.

4. Franco Ferrarotti, Des livres pour vivre, Bruxelles, La Lettre Volée, 2008.

5. Ferrarotti, Franco. "On the strained relationship between philosophy and sociology." Academicus International Scientific Journal 10 (2014): 14-19.

6. Franco Ferrarotti, Science - For What?, Chieti, Solfanelli, 2019.

7. Ferrarotti, Franco. "Science, for What? Or: Science with Conscience-The Invisible College of Dissenting Nuclear Scientists." Academicus International Scientific Journal 10.20 (2019): 12-33.

\footnotetext{
${ }^{59}$ For an admission, see L. Labedz, "Sociology as a Vocation», Survey, 49, July 1963, for the usual presentation of Western, especially American, sociology, see G. Andreeva, "The Efforts of the Bourgeois Empirical Sociology to Find a a Way out of its Crisis», Filosofskie Nauki, 5, 1962; N. Novikov, "Contemporary American Capitalism and the Action Theory of T. Parsons», Voprosy Filosofii, XVII, March 3, 1963; editorial in Kommunist, Jan. 2, 1963, «In Search of a Sociological Theory».

${ }^{60}$ Cfr. G. Karavaev, «Historical Materialism and Concrete Sociological Research», Vestnik Leningradskovo Universiteta, Seria Ekonomiki, Filosofii i Prava, XVII, 11, Nov. 1962, in which the author criticizes Rutkevich and Kogan, and indirectly old time party leaders who seem to advocate and accept concrete social research only in terms of "an application of historical materialism to the investigation of concrete phenomena».

${ }^{61}$ For some recent impressions concerning topics of common interest, see T. Parsons, "An American Impression of Sociology in the Soviet Union", American Sociological Review, 30, 1, February 1965, pp. 121-125.
} 